\title{
A case of malignant insulinoma responsive to somatostatin analogs treatment
}

\author{
Mariasmeralda Caliri ${ }^{1 \dagger}$, Valentina Verdiani ${ }^{1 \dagger}$, Edoardo Mannucci ${ }^{2}$, Vittorio Briganti ${ }^{3}$, Luca Landoni ${ }^{4}$, \\ Alessandro Esposito ${ }^{4}$, Giulia Burato ${ }^{5}$, Carlo Maria Rotella ${ }^{2}$, Massimo Mannelli ${ }^{1}$ and Alessandro Peri ${ }^{*}$
}

\begin{abstract}
Background: Insulinoma is a rare tumour representing 1-2\% of all pancreatic neoplasms and it is malignant in only $10 \%$ of cases. Locoregional invasion or metastases define malignancy, whereas the dimension (>2 cm), CK19 status, the tumor staging and grading (Ki67 > 2\%), and the age of onset (> 50 years) can be considered elements of suspect.

Case presentation: We describe the case of a 68-year-old man presenting symptoms compatible with hypoglycemia. The symptoms regressed with food intake. These episodes initially occurred during physical activity, later also during fasting. The fasting test was performed and the laboratory results showed endogenous hyperinsulinemia compatible with insulinoma. The patient appeared responsive to somatostatin analogs and so he was treated with short acting octreotide, obtaining a good control of glycemia. Imaging investigations showed the presence of a lesion of the uncinate pancreatic process of about $4 \mathrm{~cm}$ with a high sst2 receptor density. The patient underwent exploratory laparotomy and duodenocephalopancreasectomy after one month.

The definitive histological examination revealed an insulinoma (T3N1MO, AGCC VII G1) with a low replicative index (Ki67: 2\%).
\end{abstract}

Conclusions: This report describes a case of malignant insulinoma responsive to octreotide analogs administered preoperatively in order to try to prevent hypoglycemia. The response to octreotide analogs is not predictable and should be initially assessed under strict clinical surveillance.

Keywords: Insulinoma, Hypoglycemia, Somatostatin analogs, Octreotide

\section{Background}

Insulinoma is a rare tumour representing $1-2 \%$ of all pancreatic neoplasms [1]. It is malignant in only $10 \%$ of cases [2]. The malignancy can be stated only in the presence of locoregional invasion into the surrounding soft tissue, lymph node or liver metastases [3]. The dimension $>2 \mathrm{~cm}$, CK19 status, the tumor staging and grading (Ki67 $>2 \%$ ), and the age of onset $>50$ years can be considered indicators of malignancy [4-6]. However, in literature, there are some reports where about $40-50 \%$ of malignant insulinomas are $<2 \mathrm{~cm}$ [7]. Most of malignant insulinomas are sporadic (about 97\%), even if a few cases

\footnotetext{
* Correspondence: alessandro.peri@unifi.it

${ }^{+}$Mariasmeralda Caliri and Valentina Verdiani contributed equally to this work.

'Endocrine Unit, Department of Experimental and Clinical Biomedical

Sciences "Mario Serio", University of Florence, Careggi University Hospital,

Florence, Italy

Full list of author information is available at the end of the article
}

of association with MEN1 and 1 case of association with type-1 neurofibromatosis have been described [8].

In affected patients, the control of glycemia before surgical excision, or for a prolonged time if surgery is not feasible, may be very problematic. Admittedly, the description of new cases may be of help for clinicians, who have to deal with similar situations. We report a case of malignant insulinoma associated with local infiltration, neoplastic thrombosis and lymph node metastasis, in which medical treatment with octreotide effectively counteracted hypoglycemia before surgery. One peculiarity of this case is represented by the fact that short acting octreotide was used, in agreement with the surgeon, in order to avoid any possible pharmacological interference caused by long acting formulations at the time of surgery, which was performed shortly after the diagnosis.

(c) The Author(s). 2018 Open Access This article is distributed under the terms of the Creative Commons Attribution 4.0 International License (http://creativecommons.org/licenses/by/4.0/), which permits unrestricted use, distribution, and reproduction in any medium, provided you give appropriate credit to the original author(s) and the source, provide a link to the Creative Commons license, and indicate if changes were made. The Creative Commons Public Domain Dedication waiver (http://creativecommons.org/publicdomain/zero/1.0/) applies to the data made available in this article, unless otherwise stated. 


\section{Case presentation}

A 68-year-old man presented a weight increase of $7 \mathrm{~kg}$ during the last year and symptoms compatible with hypoglycemia (objective vertigo, feeling of an empty head, sweating, palpitations). During some of these episodes low blood glucose levels $(<40 \mathrm{mg} / \mathrm{dl})$ were documented by glucometer measurement. The symptoms regressed with food intake. These episodes initially occurred during physical activity and later also during fasting.

He had no family history of endocrine disease.

At admission, his body mass index was $28 \mathrm{~kg} / \mathrm{m}^{2}$. The rest of the physical examination was unremarkable. Biochemical assessment did not show any abnormality, and glucose level was $70 \mathrm{mg} / \mathrm{dl}$ (n.v. 65-110). Plasma cortisol at $8 \mathrm{a} . \mathrm{m}$. was in the normal range $(394.8 \mathrm{nmol} / \mathrm{l}$, n.v. 138-685 nmol/l), anti-insulin antibodies were negative, chromogranin A was $69 \mathrm{ng} / \mathrm{ml}$ (n.v. 10-185), prolactin was $247 \mathrm{mU} / \mathrm{l}$ (n.v. 53-369), gastrin was $12.7 \mathrm{pg} / \mathrm{ml}$ (n.v. $<180$ ), PTH was $6.4 \mathrm{pmol} / \mathrm{l}$ (n.v. 1-6.8) and serum calcium level was $8.8 \mathrm{mg} / \mathrm{dl}$ (n.v. 8.6-10.4).

The fasting test was performed, which was interrupted after $12 \mathrm{~h}$ due to the onset of symptomatic hypoglycemia ( $44 \mathrm{mg} / \mathrm{dl}$, glucometer measurement). Plasma glucose level was $41 \mathrm{mg} / \mathrm{dl}$, insulin level $16.3 \mathrm{U} / \mathrm{L}$ and C-peptide $1.27 \mathrm{nmol} / \mathrm{l}$ (Table 1). Per protocol, $1 \mathrm{mg}$ of glucagon was injected intravenously after interruption of the fasting test and plasma glucose was measured (time $0^{\prime}, 41$ $\mathrm{mg} / \mathrm{dl}$; after $10 \mathrm{~min} 75 \mathrm{mg} / \mathrm{dl}$, after $20 \mathrm{~min} 94 \mathrm{mg} / \mathrm{dl}$ and after $30 \mathrm{~min} 93 \mathrm{mg} / \mathrm{dl}$ ). The patient's laboratory results showed endogenous hyperinsulinemia, according to published guidelines (fasting test: plasma glucose $<55 \mathrm{mg} / \mathrm{dl}$, with insulin and C-peptide levels $>3 \mathrm{U} / \mathrm{L}$ and $>0.2$ $\mathrm{nmol} / \mathrm{L}$, respectively; glucagone test: $>25 \mathrm{mg} / \mathrm{dL}$ increase of glucose levels after fasting) [9]. The short octreotide test (subcutaneous infusion of $100 \mathrm{mg}$ of short-term octreotide at $7.00 \mathrm{a} . \mathrm{m}$. after an overnight fast, and blood glucose, insulin and C-peptide hourly sampling for six hours) was performed to evaluate the efficacy of a possible treatment with somatostatin analogs, in order to counteract hypoglycemia [10]. No food was allowed during the test. The test showed an increase in plasma glucose above $100 \mathrm{mg} / \mathrm{dl}$ (Table 2), and the patient was considered to be responsive to somatostatin analogs [10].
Table 2 Short term octreotide test. The test was performed according to ref. [2]

\begin{tabular}{llllllll}
\hline & $0^{\prime}$ & $1 \mathrm{~h}$ & $2 \mathrm{~h}$ & $3 \mathrm{~h}$ & $4 \mathrm{~h}$ & $5 \mathrm{~h}$ & $6 \mathrm{~h}$ \\
\hline $\begin{array}{l}\text { Glycemia } \\
\text { (basal 65-110 mg/dL) }\end{array}$ & 54 & 61 & 116 & 134 & 133 & 130 & 122 \\
$\begin{array}{l}\text { Insulin level } \\
\text { (basal 3-17 U/L) }\end{array}$ & 16.8 & 2.5 & 3.1 & 4.3 & 4.5 & 5.2 & 6 \\
$\begin{array}{l}\text { C-peptide } \\
\text { (basal 0.37-1.47 nmol/L) }\end{array}$ & 1.39 & 0.56 & 0.49 & 0.51 & 0.54 & 0.56 & 0.59 \\
\hline
\end{tabular}

Additional procedures included:

- MRI, which revealed a lesion of the uncinate pancreatic process of about $4 \mathrm{~cm}$, which presented a brief contact with the upper mesenteric artery and a $>180^{\circ}$ contact with the superior mesenteric vein with suspected infiltration (Fig. 1).

- Octreoscan, which showed a lesion located in the pancreatic site, with a high somatostatin receptor (sstR) density (Fig. 2).

- Abdominal CT scan with contrast, which revealed a polylobed lesion with sharp margins at the level of the uncinate pancreas process, in contact with the superior mesenteric vein and reaching the margins of the superior mesenteric artery. No signs of vessels infiltration were observed.

All these imaging procedures were indicative of the presence of an insulinoma as the cause of endogenous hyperinsulinemia.

Surgical treatment was scheduled. Before surgery, considering the response to the short octreotide test, the patient was treated with short acting octreotide $(0.1 \mathrm{mcg}$ twice a day), obtaining a good control of glycemia by glucometer measurement, disappearance of hypoglycemic symptoms and no recurrence of hypoglycemic episodes.

The patient underwent exploratory laparotomy and duodenocephalopancreasectomy after one month.

The postoperative course was complicated by the appearance of a pancreatic (grade B) [11] and a biliary fistula, whereby the patient was conservatively treated with fasting and parenteral nutritional intake and subsequenty via a naso-enteral tube. The control CT scan,

Table 1 Fasting test results. The test has been performed according to the Endocrine Society Clinical Pratice Guidelines on adult hypoglycemic disorders (ref [9])

\begin{tabular}{|c|c|c|c|c|c|c|}
\hline & 12 a.m. & 2 a.m. & 4 a.m. & 8 a.m. & 10 a.m. & 12 p.m \\
\hline Glucometer measurement mg/dL & 111 & 68 & 67 & 66 & 62 & 45 \\
\hline Glycemia (basal 65-110 mg/dL) & & 70 & & 58 & & 41 \\
\hline Insulin level (basal 3-17 U/L) & & 8.7 & & 13.3 & & 16.3 \\
\hline C-peptide (basal 0.37-1.47 nmol/L) & & 1.11 & & 1.03 & & 1.27 \\
\hline
\end{tabular}




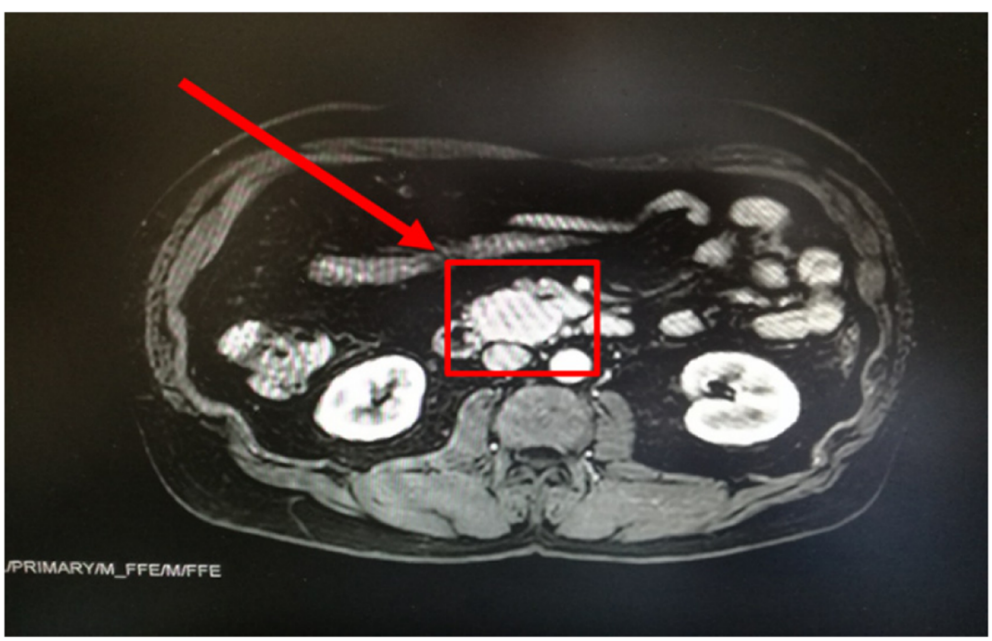

Fig. 1 Abdominal MRI showing a solid tumor with definite margins of the uncinate pancreatic process of $4 \times 3 \times 3.5 \mathrm{~cm}$

performed a month later, did not reveal intra-abdominal spill and drainages were removed. Oral feeding was resumed one month after the operation.

The definitive histological examination revealed a neuroendocrine tumor with insulin receptors (insulinoma) of 3.5 $\mathrm{cm}$ infiltrating the duodenum, retroperitoneal adipose tissue, with widespread neoplastic thrombosis, and with metastasis in 3 pancreatic-duodenal lymph nodes among the 48 that had been surgically removed (T3N1MO, AjCC VIII edition G1), with a low replicative index (Ki67: 2\%); radical resection (R0). Vascular and adipose tissue infiltration by the tumor, which are indicative of malignancy, were observed. Immunohistochemical staining was positive for insulin and synaptophysin (Fig. 3).

The most recent abdominal MRI, performed 6 months after surgery, did not reveal any recurrence of disease and currently the patient is in good conditions and with normal glycemic levels.

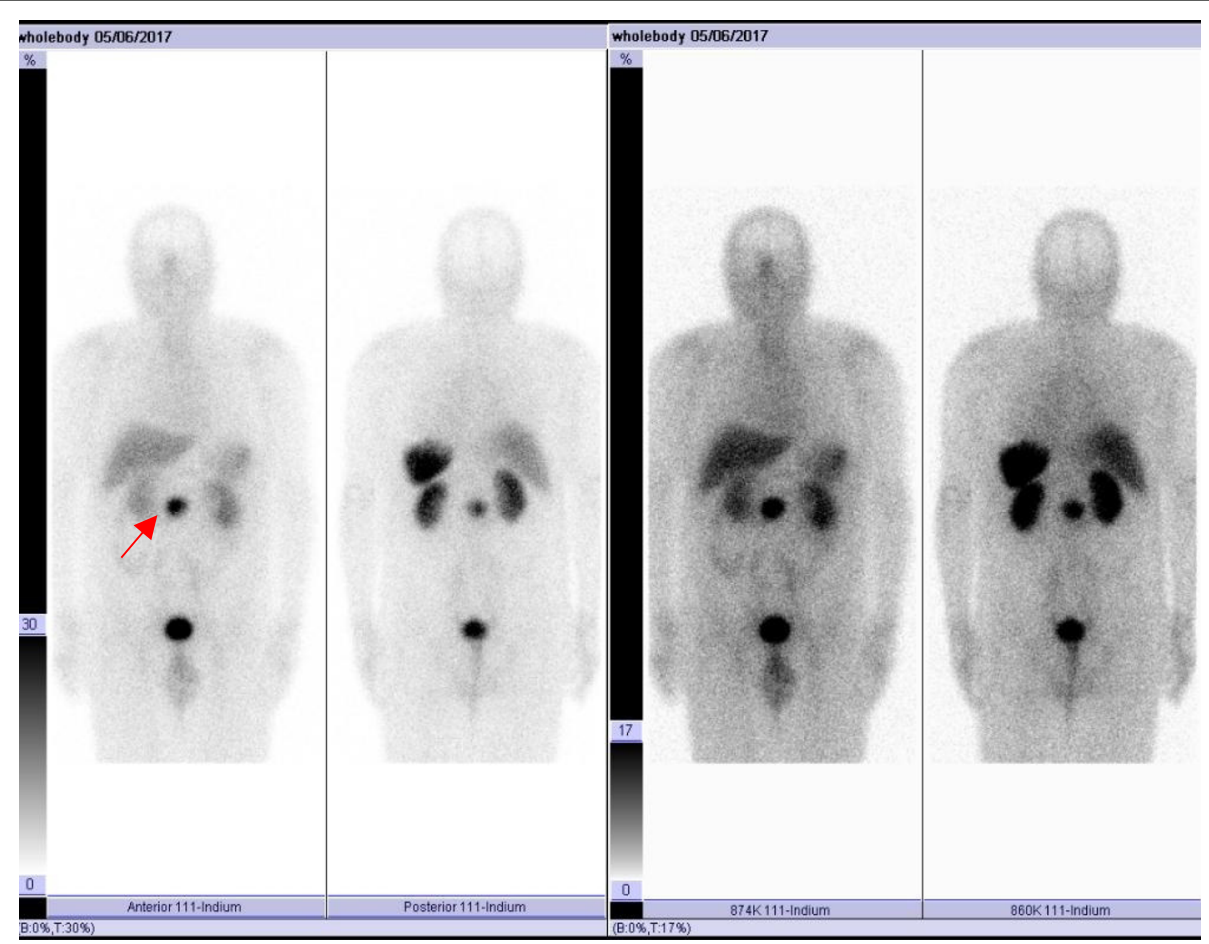

Fig. 2 Octreoscan showing a lesion localized in the pancreatic site, with high sstR density 

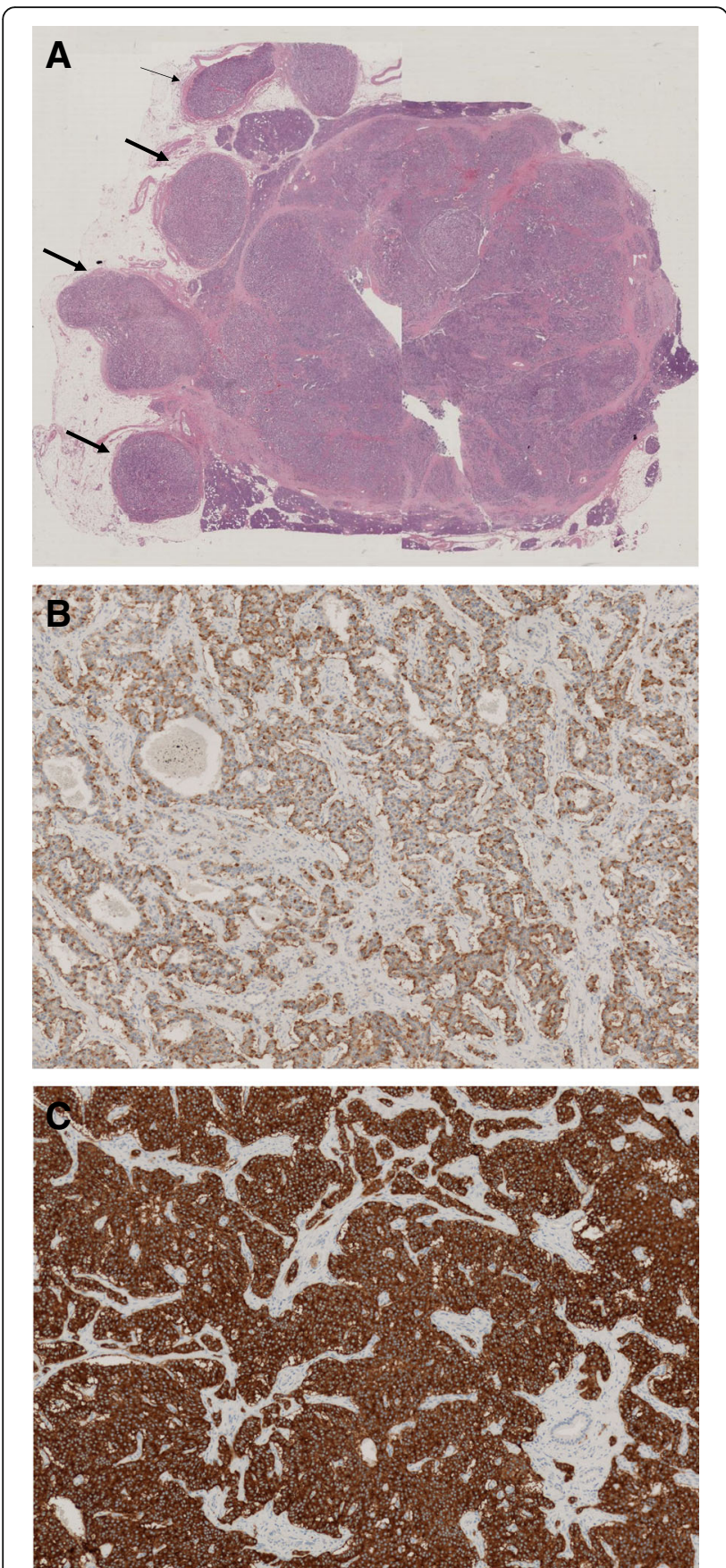

Fig. 3 a Macrosection of the neoplasia showing vascular (thin arrow) and adipose tissue (thick arrows) infiltration by the tumor. b-c

Immunohistochemical staining for insulin and synaptophysin, respectively

\section{Discussion and conclusions}

Clinical hypoglycemia occurs when plasma glucose concentration is low enough to cause symptoms and/or signs, which include neurological alterations. The clinical feautures of hypoglycemia are non specific and it is not possible to establish a single plasma glucose concentration that definitively confirms clinical hypoglycemia.
Therefore, hypoglycemia is confirmed by the documentation of the Whipple's triad [12], e.g. symptoms and/or signs consistent with hypoglycemia, a low plasma glucose concentration, and resolution of clinical alterations after the plasma glucose concentration is increased $[12,13]$.

The most common cause of hypoglycemia is represented by insulin, insulin secretagogues, alcohol abuse and drugs of different classes [14]. Hypoglycemia may occur during sepsis and other critical illnesses, which include renal or hepatic failure. Hypoglycemia can be also secondary to cortisol deficiency [15]. It is therefore reasonable to assess plasma cortisol in the presence of hypoglycemia, although adrenocortical failure is not a common cause of hypoglycemia in adults in the absence of other clinical evidence. A low plasma cortisol concentration found in the presence of hypoglycemia is not per se indicative of adrenocortical insufficiency. In fact, recurrent hypoglycemia shifts glycemic thresholds for cortisol secretion [16].

Hypoglycemia may be caused by hyperinsulinism in the absence of prior gastric surgery or after Roux-en-Y gastric bypass for obesity [15]. It can also be associated to the presence of anti-insulin antibodies, such as in Hirata syndrome [17]. Finally, hyperinsulinemic hypoglycemia may be due to uncontrolled insulin release either from tumoral pancreatic beta-cells or from functionally defective beta-cells, as observed in nesidioblastosis, which is usually seen in newborns [18].

Although rare, insulinoma is the most common neuroendocrine tumor of the pancreas with an annual incidence of four in every 1 million persons. Malignancy is observed in only $10 \%$ of cases [2]. The clinical manifestation of insulinoma are variable and nonspecific and are related to the presence of hypoglycemia. The symptoms, which are often precipitated during physical exercise, become typically evident after fasting. The 72-h fasting test remains the gold standard for the diagnosis of insulinoma and includes the measurement of plasma glucose, insulin, C-peptide, at the time hypoglycemic symptoms appear [19]. We used this test for the diagnosis of primary hyperinsulinism in our case and the severe hypoglycemia with measurable insulin levels occurred after only $12 \mathrm{~h}$ unequivocally confirmed the hypothesis.

Non-invasive imaging procedures, such as CT and MRI, are used when a the biochemical diagnosis of primary hyperinsulinism has been made. Invasive modalities, such as endoscopic ultrasonography and arterial stimulation venous sampling, have frequently been shown to be superior to non-invasive localization techniques to preoperatively localize insulinomas [19]. Numerous studies have shown that the cell surface in neuroendocrine tumors (NETs) express sstR and have led to the development of new localization techniques. 11In-[DTPA-D-Phe1] octreotide scintigraphy (Octreoscan) can be used for the localization 
of primary tumours and their metastases in patients presenting with the clinical and biochemical features of NETs [20]. However only $20-50 \%$ of insulinoma can be dectected by octreoscan with planar imaging [10, 21, 22], although it has been described that the use of SPECT improves the detection of insulinomas by octreoscan scintigraphy [23]. GLP-1R imaging by ${ }^{111}$ In-DOTA-exendin-4 administration is another non-invasive diagnostic approach that may succesfully localize small insulinomas pre- and intraoperatively [24]. Very recently, the ENETS guidelines recommend ${ }^{68} \mathrm{Ga}$-DOTA-somatostatin analog $\mathrm{PET} / \mathrm{CT}$, because it is largely superior to somatostatin receptor scintigraphy, and facilitates the diagnosis of most types of NET lesions [25]. In our patient MRI showed the presence of a lesion of the uncinate pancreatic process of about $4 \mathrm{~cm}$. Subsequent octreoscan revealed that the lesion expressed high levels of sstR.

Surgery is the first choice therapy for resectable insulinomas. A pharmacological approach can be useful both during the preoperative period, and for preventing hypoglycaemia in insulinomas with unknown localization. Diazoxide can prevent hypoglycemia by suppressing the release of insulin from insulinoma cells via opening ATP-sensitive potassium channels [26]. The use of this drug may be limited by side effects, such as hypotension, water retention with declining edema, hyperuricaemia, hypertriglyceridaemia, thrombocytopenia and neutropenia. Somatostatin analogs represent another possible medical strategy to suppress uncontrolled insulin secretion and control the symptoms of hypoglycemia in patients with insulinoma [27]. They can be used for instance in patients who are not eligible for surgery and when diazoxide is not applicable due to its inefficiency or adverse effects. In malignant insulinomas the use of somatostatin analogs may have an additional indication, due to the antiproliferative and moderate antineoplastic activity of these molecules [28-31].

It has to be said that the response to somatostatin analogs may differ according to the presence of various subtypes of sstR on insulinoma cells. Octreotide binds predominantly to sstR subtype 2 . The absence of these receptors on insulinoma cells may aggravate hypoglycemia when a patient is treated with octreotide. This effect may be due to the inhibition of contra-insular hormones such as growth hormone and glucagon by somatostatin [32, 33]. The glycemic response to somatostatin analogs in any single patient is unpredictable and for this reason testing the drug while the patient is hospitalized is mandatory. In the case we described, a very good response was obtained with octreotide administration and the patient did not experience any new hypoglycemic episode before surgery.

In summary, we have described a rare case of malignant insulinoma in a patient with recurrent hypoglycemic episodes. The patient was successfully treated with short acting octreotide analogs before surgery, after testing its efficacy on glycemic control. No disease recurrence was observed at 6 month after surgery and the condition of the patient is currently very satisfactorily.

\section{Abbreviations}

CT scan: Computed Tomography scan; MEN-1: Multiple Endocrine neoplasia1; MRI: Magnetic Resonance Imaging; PTH: Parathyroid hormone

\section{Acknowledgements \\ $\mathrm{N} / \mathrm{A}$ \\ Funding \\ $\mathrm{N} / \mathrm{A}$ \\ Availability of data and materials \\ N/A \\ Authors' contributions \\ $M C$ and $W$ contributed to the patient's clinical care and preparation of the manuscript; VB contributed to octreoscan imaging and revision of the manuscript, $L L$ and $A E$ contributed to surgery and revision of the manuscript, GB contributed to histopathological assessment and revision of the manuscript, EM, CRM, MM and AP contributed to the patient's clinical care, revision and final approval of the manuscript of the manuscript.}

Ethics approval and consent to participate

Ethical approval N/A and informed consent to participate to the study was obtained from the patient.

Consent for publication

It was obtained from the patient in written form.

\section{Competing interests}

The authors declare that they have no competing interests.

\section{Publisher's Note}

Springer Nature remains neutral with regard to jurisdictional claims in published maps and institutional affiliations.

\section{Author details}

${ }^{1}$ Endocrine Unit, Department of Experimental and Clinical Biomedical Sciences "Mario Serio", University of Florence, Careggi University Hospital, Florence, Italy. ${ }^{2}$ Diabetology Unit, Department of Experimental and Clinical Biomedical Sciences "Mario Serio", University of Florence, Careggi University Hospital, Florence, Italy. ${ }^{3}$ Division of Nuclear Medicine, Careggi University Hospital, Florence, Italy. ${ }^{4}$ General and Pancreatic Surgery Department, The Pancreas Institute-University of Verona Hospital Trust, Verona, Italy.

${ }^{5}$ Department of Pathology and Diagnostics, University of Verona Hospital Trust, Verona, Italy.

Received: 8 April 2018 Accepted: 13 December 2018

Published online: 27 December 2018

\section{References}

1. Oberg K, Eriksson B. Endocrine tumours of the pancreas. Best Pract Res Clin Gastroenterol. 2005;19:753-81.

2. Hirshberg B, Cochran C, Skarulis MC, Libutti SK, Alexander HR, Wood BJ, et al. Malignant insulinoma: spectrum of unusual clinical features. Cancer. 2005; 104:264-72.

3. Grant CS. Insulinoma. Best Pract Res Clin Gastroenterol. 2005:19:783-98.

4. Jonkers YM, Claessen SM, Veltman JA, Geurts van Kessel A, Din-jens WN, Skogseid B, et al. Molecular parameters associated with insulinoma progression: chromosomal instability versus p53 and CK19 status. Cytogenet Genome Res. 2006:115:289-97.

5. Pape UF, Berndt U, Müller-Nordhorn J, Böhmig M, Roll S, Koch M, et al. Prognostic factors of long-term outcome in gastroenteropancreatic neuroendocrine tumours. Endocr Relat Cancer. 2008;15:1083-97. 
6. Pape UF, Jann H, Müller-Nordhorn J, Bockelbrink A, Berndt U, Willich SN, et al. Prognostic relevance of a novel TNM classification system for upper gastroenteropancreatic neuroendocrine tumors. Cancer. 2008;113:256-65.

7. E B, Caron P, Lombard-Bohas C, Tabarin A, Mitry E, Reznick Y, et al. Malignant insulinoma: recommendations for characterisation and treatment. Ann Endocrinol. 2013;74:523-33.

8. Perren A, Wiesli P, Schmid S, Montani M, Schmitt A, Schmid C, et al. Pancreatic endocrine tumors are a rare manifestation of the neurofibromatosis type 1 phenotype: molecular analysis of a malignant insulinoma in a NF-1 patient. Am J Surg Pathol. 2006;30:1047-51.

9. Cryer PE, Axelrod L, Grossman AB, Heller SR, Montori VM, Seaquist ER, Service FJ, Endocrine Society. Evaluation and management of adult hypoglycemic disorders: an Endocrine Society clinical practice guideline. J Clin Endocrinol Metab. 2009;94:709-28.

10. Vezzosi D, Bennet A, Rochaix P, Courbon F, Selves J, Pradere B, et al. Octreotide in insulinoma patients: efficacy on hypoglycemia, relationships with octreosacan scintigraphy and immunostaining with anti-sst2A and anti-sst5 antibodies. Eur J Endocrinol. 2005;152:757-67.

11. Bassi C, Marchegiani G, Dervenis C, Sarr M, Abu Hilal M, Adham M, et al. The 2016 update of the international study group (ISGPS) definition and grading of postoperative pancreatic fistula: 11 years after. Surgery. 2017;161:584-91.

12. Whipple AO. The surgical therapy of hyperinsulinism. J Int Chir. 1938;3:237-76.

13. Cryer PE. Symptoms of hypoglycemia, thresholds for their occurrence, and hypoglycemia unawareness. Endocrinol Metab Clin N Am. 1999;28:495-500.

14. Murad MH, Coto-Yglesias F, Wang AT, Sheidaee N, Mullan RJ, Elamin MB, et al. Clinical review: drug-induced hypoglycemia: a systematic review. J Clin Endocrinol Metab. 2009:94:741-5.

15. Nieman LK, Chanco Turner M. Addison's disease. Clin Dermatol. 2006;276-80.

16. A M, Fanelli C, Veneman T, Perriello G, Calderone S, Platanisiotis D, et al. Reversibility of unawareness of hypoglycemia in patients with insulinomas. N Engl J Med. 1993;329:834-9.

17. Gullo D, Evans JL, Sortino G, Goldfine ID, Vigneri R. Insulin autoimmune syndrome (Hirata disease) in European Caucasians taking a-lipoic acid. Clin Endocrinol. 2014:81:204-9.

18. Raffel A, Raffel A, Krausch MM, Anlauf M, Wieben D, Braunstein S, Klöppel G, et al. Diffuse nesidioblastosis as a cause of hyperinsulinemic hypoglycemia in adults: a diagnostic and therapeutic challenge. Surgery. 2007;141:179-84.

19. Okabayashi T, Shima Y, Sumiyoshi T, Kozuki A, Ito S, Ogawa Y, et al. Diagnosis and management of insulinoma. World J Gastroenterol. 2013;19: 829-37.

20. Shi W, Johnston CF, Buchanan KD, Ferguson WR, Laird JD, Crothers JG, Mcilrath EM. Localization of neuroendocrine tumours with [111/n] DTPAoctreotide scintigraphy (Octreoscan): a comparative study with $C T$ and MR imaging. Q J Med. 1998;91:295-301.

21. Krenning EP, Kwekkeboom DJ, Bakker WH, Breeman WA, Kooij PP, Oei HY, et al. Somatostatin receptor scintigraphy with [111/n-DTPA-D-Phe1]- and [123ITyr3]-octreotide: the Rotterdam experience with more than 1000 patients. Eur J Nucl Med. 1993;20:716-31.

22. de Herder WW, Kwekkeboom DJ, Valkema R, Feelders RA, van Aken MO, Lamberts SW, et al. Neuroendocrine tumors and somatostatin: imaging techniques. J Endocrinol Investig. 2005;28:132-6.

23. Schillaci O, Massa R, Scopinaro F. 111ln-pentetreotide scintigraphy in the detection of insulinomas: importance of SPECT imaging. J Nucl Med. 2000 41:459-62.

24. Christ E, Wild D, Forrer F, Brändle M, Sahli R, Clerici T, et al. Glucagon-like peptide-1 receptor imaging for localization of insulinomas. J Clin Endocrinol Metab. 2009:94:4398-444.

25. Sundin A, Arnold R, Baudin E, Cwikla JB, Eriksson B, Fanti S, et al. ENETS consensus guidelines for the standards of Care in Neuroendocrine Tumors: radiological, Nuclear Medicine \& Hybrid Imaging. Neuroendocrinology. 2017; 105:212-44

26. Gill GV, Rauf O, MacFarlane IA. Diazoxide treatment for insulinoma: a national UK survey. Postgrad Med J. 1997;73:640-1

27. Matej A, Bujwid H, Wroński J. Glycemic control in patients with insulinoma. Hormones (Athens). 2016;15:489-99.

28. Romeo S, Milione M, Gatti A, Fallarino M, Corleto V, Morano S, Baroni MG. Complete clinical remission and disappearance of liver metastases after treatment with somatostatin analogue in a 40-year-old woman with a malignant insulinoma positive for somatostatin receptors type 2 . Horm Res. 2006;65:120-5
29. Usukura M, Yoneda T, Oda N, Yamamoto Y, Takata H, Hasatani K, Takeda Y Medical treatment of benign insulinoma using octreotide LAR: a case report. Endocr J. 2007:54:95-101.

30. Jawiarczyk A, Bolanowski M, Syrycka J, Bednarek-Tupikowska G, Kałużny M, Kołodziejczyk A, Domosławski P. Effective therapy of insulinoma by using long-acting somatostatin analogue. A case report and literature review. Exp Clin Endocrinol Diabetes. 2012;120:68-72.

31. Baudin E, Caron P, Lombard-Bohas C, Tabarin A, Mitry E, Reznick Y, et al. Malignant insulinoma: recommendations for characterisation and treatment. Ann Endocrinol (Paris). 2013;74:523-33.

32. Stehouwer CDA, Lems WF, Fischer HRA, Hackeng WHL, Naafs MAB. Aggravation of hypoglycemia in insulinoma patients by the long-acting somatostatin analogue octreotide (Sandostatin). Acta Endocrinol. 1989;121: 34-40.

33. Appetecchia M, Baldelli R. Somatostatin analogues in the treatment of gastroenteropancreatic neuroendocrine tumours, current aspects and new perspectives. J Exp Clin Cancer Res. 2010;29:19.

\section{Ready to submit your research? Choose BMC and benefit from:}

- fast, convenient online submission

- thorough peer review by experienced researchers in your field

- rapid publication on acceptance

- support for research data, including large and complex data types

- gold Open Access which fosters wider collaboration and increased citations

- maximum visibility for your research: over $100 \mathrm{M}$ website views per year

At BMC, research is always in progress.

Learn more biomedcentral.com/submissions 